\title{
1. Towards a multilevel European democracy
}

\section{INTRODUCTION}

The legitimacy of the European Union (EU) has been questioned for more than 20 years, since the referendums in Denmark and France on the Treaty of Maastricht took European leaders and EU institutions by surprise, signalling an unexpected disillusionment with the European project. Since then, the academic community has been pondering about the so-called EU 'democratic deficit', giving rise to a rich and complex literature. The democratic deficit of the European Union (henceforth also appearing in this text as 'Union') has been the object of very different assessments. Opinions range from those who think that the problem is very serious and may threaten the very sustainability of the Union, to those who think that the problem does not really exist. The authors of this book believe that it should be taken seriously, but they also think that the notion of democracy by which the EU is to be evaluated needs to be adapted to the 'new circumstances of politics' (Rawls 1972, Weale 1999) characteristic of a multilevel setting like the European Union. Our attempt will therefore be to review some of the more recent contributions on representative democracy in multilevel settings in order to extrapolate the criteria according to which democracy should function in these contexts. We may discover that, in such settings, the role of a committee like the Committee of the Regions (CoR) is less marginal than it might appear should we instead stick to a more conventional notion of democracy as borrowed from, and applicable exclusively to, national settings.

In what follows we will first review the 'standard version' of the democratic deficit thesis in order to highlight the main flaws in the legitimacy bases of the Union identified by the literature and the main solutions advanced to amend them. We will then delve into the recent literature on democracy in interconnected settings 
and highlight the distinctive problems that such settings present to democratic theory and practice. We will thus be able to identify the weaknesses or at least the partiality of some of the more conventional recipes that can be found in the literature and the extra mileage that can instead be gained by taking seriously some of the more recent developments in democratic theory. We will finally be able to put into relief the contribution that the CoR can make to EU democracy, which is in fact the main aim of this volume.

\section{THE STANDARD VERSION OF THE DEMOCRATIC DEFICIT}

The 'standard version' of the democratic deficit can be found in Weiler, Haltern and Mayer (1995) and in Føllesdal and Hix (2006). The democratic deficit of the European Union has been attributed to five related factors, which have to do with the particular institutional architecture of the Union and the unconventional - vis-à-vis national democracies - division of labour that exists among its institutions. Despite the significant differences that exist among EU democracies, EU citizens have certain expectations when it comes to democratic government. Most European citizens live in some variant of parliamentary democracy, with the exception of France, which is a semi-presidential system, and Portugal, Poland and Finland, which are sometimes classified as semi-parliamentary systems because of the particular strength of their presidency. This means that most citizens expect the composition of the executive to be determined by the results of parliamentary elections, whether directly or indirectly.

Moreover, they are used to being able to assign blame or give credit to the executive for the effectiveness of its governmental action and to follow through by 'throwing the rascals out' or by renewing confidence in the party or parties that compose the governmental majority or otherwise support the executive. In other words, they are used to living in parliamentary representative democracies. While there are remarkable differences between majoritarian and consensus democracies, particularly in the extent to which blame or merit can be unequivocally placed on the governmental majority and is not shared also by other parties (Lijphart 1999), in parliamentary democracies elections still normally serve the purpose of determining the composition and political orientation of the executive. Not so in 
the EU, where elections to the European Parliament (EP) have so far had very little impact, if any, on the orientation of what might be termed the 'EU executive' (Steunenberg and Thomassen 2002). This orientation in turn is determined by several other exceptional traits of EU government and it is all the more significant as 'European integration has meant an increase in executive power and a decrease in national parliamentary control' (Føllesdal and Hix 2006: 534).

The first and most obvious distinctive trait of the EU institutional setting is that 'the EU executive' is a complex mix of EU and national parts. By 'EU executive' we would certainly understand the European Commission (Commission) in both its directly implementative role and in its indirectly supervisory role (the Commission, in fact, implements some EU policies both directly and through delegated agencies, in turn sometimes networks of national agencies; see Christiansen and Larsson 2007). However, in the executive of the EU we would also necessarily have to include the national executives that, through their ministerial bureaucracies, do most of the on-theground implementation, again either directly or indirectly through more or less independent administrative agencies. Last, but not least, we have to include in the EU executive the subnational bureaucracies that implement many EU policies either exclusively or in collaboration with national bureaucracies. Clearly, this complex executive system does not respond to any one electoral result, but either to several or to none at all. National and subnational executives (in most cases) reflect the result of national and subnational elections, while the political orientation of the Commission has so far been largely unrelated to the outcome of the EP elections. Conventional wisdom has it (Hooghe 2001) that the Commission, being at the top level composed of politicians who are appointed by national executives, reflects the political orientation of the latter and hence presents a rather mixed political profile. In recent times, that is at least since the appointment of Romano Prodi as president of the Commission in 1999, national executives have tried to align the political orientation of the president of the Commission to that of the EP, and with the 2014 elections for the first time European parties indicated their own candidates to the presidency of the Commission, thus creating a more direct linkage between EP parliamentary majority and the political orientation of the Commission. It is still the case, though, that the president of the Commission has limited freedom of manoeuvre when it comes to selecting the other members of the 
College of Commissioners, who are proposed by national executives, and there is a limit to the degree of purely party-political influence the European Parliament can exercise through its hearings.

The elections of the European Parliament do not really determine the political composition of the EU executive also for a second, crucial reason. EP elections are 'second-order national elections' (Reif and Schmitt 1980, Marsh 1998, Marsh and Mikhaylov 2010), being still largely fought and won over national issues rather than over genuinely EU issues. The literature has moreover detected a curious 'inversion of roles' between the European and the national parliaments: while the European Parliament should in theory discuss and decide on the policy issues over which the EU has competence and the national parliaments should discuss and decide which competences they wish to attribute to the EU, national parliaments still debate policy issues as if they exclusively could decide on them and parties run for EP elections as if they could there decide over EU competences (Mair 2000). In other words, national parliaments still function as if they could directly influence EU policy-making, while the European Parliament functions as a sort of organized opposition to an executive - composed of the Commission, the Council of the European Union (henceforth also appearing in the text as 'Council') and the European Council - which it does not select. While the acuteness of this phenomenon may have declined over time (Mair and Thomassen 2010), it is however true that the European Parliament still tends to host a disproportionate number of representatives who in national parliaments would sit on the opposition benches, lending a particular 'oppositional' tone to parliamentary debates (Farrell and Scully 2010). In part, also for this reason, the EP is normally governed by 'grand coalitions' of pro-EU parties, which reinforces the image of a European Parliament split between those who oppose the EU (often because they oppose their national governments) and those who support the EU no matter what. In no case does the European Parliament correspond to the conventional expectations of how the parliaments of most European states would behave (we will challenge this view below). Moreover, national parliaments have objectively been side-lined when it comes to EU policy-making - given the real difficulty for most of them to keep abreast of the issues discussed at EU level, let alone give their timely input, and the limited control mechanisms which they had been given over policy outcomes, at least until the Treaty of Lisbon. 
The third reason for the lack of connection between EP elections and the composition of the 'executive' is the fact that EU elections have so far been hardly 'European' at all. Candidates to the European Parliament have for a long time been appointed by national parties on the basis of criteria that had nothing to do with the EU. Particularly in the beginning, they were either very junior or very senior members of the national parties, and hence without much experience or commitment to the EP. In most cases they were unknown to their national electorates and they did not make much of an effort to make themselves known. This state of affairs was perhaps understandable. In its early days, the European Parliament had very little legislative power, only being asked for its opinion (consultation procedure) or its consent (assent procedure). In time, the EP acquired increasing decision-making powers (through the cooperation and then the early version of the codecision procedure) until, with the Treaty of Maastricht and subsequent treaties, it acquired colegislative powers on a par with the EU Council (under the later versions of the codecision procedure and then the ordinary legislative procedure introduced by the Treaty of Lisbon). With the increase in EP legislative powers, a representative seat in the EP has become a more coveted position and more central political figures have started to run for EP elections. Consequently a European-level representative class has begun to develop, which understands its political career almost exclusively within EU institutions (Scully 2005, Raunio 2009, Auel and Christiansen 2015). Despite this evident process of parliamentary institutionalization and the slowly growing salience of European issues, which was also reflected in the efforts of major European parties to run more 'European' campaigns for their candidates for Commission president in 2014, even today EU elections remain somehow separate second-order national elections at the level of both the political personnel and the attitudes of national political parties.

Fourth, EU elections are not really democratic, so the argument goes, because there is no 'European public sphere': there is no one single debate on Europe, but many separate national debates (Koopmans and Statham 2010, Lacroix and Nicolaidis 2010). Each of these debates refers to national issues and tends to assess the EU through purely 'national interest' lenses, however differently these may be interpreted by the various parties. Language barriers and prevalent national identities prevent Europeans from 
engaging in cross-national debates and lock politicians into national political discourses, despite the emergence of multiple identities and transnational public spheres (Risse 2010). Some scholars arrive at somewhat similar conclusions starting from a completely different premise. They argue that the issues over which the EU has competence are fairly technical and low-salience and that, for this reason, European citizens are not too interested in them (Moravcsik 2002). If these issues were more genuinely 'political' - having to do with taxation, welfare or culture, for example - then European citizens would certainly get more engaged at EU level and would correspondingly demand more democracy at this level. Since the Union does not really engage in truly contentious and political issues, EU citizens allegedly remain detached and uninterested in EU politics. This argument, which has been challenged by Føllesdal and Hix (2006) and Hix (2008), is particularly counter-intuitive at a time, like the present time, when the euro crisis has made EU-level monetary and macroeconomic policies extremely relevant for the lives of European citizens and when some EU decisions are the object of heated debates in most European member states (cf. Majone 2014).

The lack of a European public sphere is at the same time effect and cause of the internal fragmentation of the European demos in distinct national demoi. The 'no-demos thesis' (Weiler, Haltern and Mayer 1995), then, is the fifth and probably strongest reason why, according to the standard view, democracy at EU level cannot function like it does at national level, if at all. Politics is about making difficult decisions that have an impact on the lives of EU citizens, particularly when they have a clear redistributive effect. In the absence of a 'wefeeling' such issues cannot really be discussed and decided, hence it is only appropriate that the EU should not have competence over them. But is this really so? Are the decisions that are the bread and butter of EU politics purely regulatory decisions (Majone 1999) that need only mobilize technical expertise and give rise to Pareto-optimal, hence non-contentious, decisions? Must there be an EU demos before any truly political issue can be discussed and decided at EU level? Or does not a sense of belonging grow out of the discussions surrounding any such issues? How else can an EU demos come into being? Here the 'no-demos thesis' and Jürgen Habermas's (2001a, b) argument in favour of 'civic patriotism' and the existence of a sense of EU solidarity clash. These are the issues that first spurred the 'democratic deficit' thesis and which appeared to seal it forever. 
While these five reasons belong to two different analytical strands - one that focuses on temporary and evolving institutional issues and one that highlights relatively immutable existential conditions - it is clear that they all depend upon an understanding of democracy as predicated upon the same conditions that would apply in national democracies. The European Union, though, is a different sort of construct: one that takes the growing interdependence of EU member states seriously and that was in fact created in order to bank upon and intensify that interdependence. Democracy in interdependent settings must be rethought afresh and must develop its own criteria, even while starting from known foundational principles. As Bohman (2007: 2) puts it, '. . . the proper solution to the problems of democracy is not to find some optimal size or ideal democratic procedure, but rather to establish a more complex democratic ideal'.

\section{DEMOCRACY AS NON-DOMINATION}

It is beyond doubt that nation-states - whether by conscious choice or because of external forces over which they have little control - are no longer fully capable of controlling the circumstances in which their citizens live, and therefore encounter increasing difficulties in realizing democracy as it is conventionally understood. State sovereignty - including an internal dimension having to do with control of subnational units and civil society organizations, an external dimension having to do with autonomy over policy-making in an increasingly interdependent world and a legal dimension having to do with the distinctiveness of the public interest vis-à-vis private interests (Piattoni 2010a: 17-31) - is an outdated concept. Some argue that, in fact, states never really were completely sovereign in this sense, but it is still true that the rhetoric of sovereignty as 'unencumbered self-rule' has been, and still is, at the basis of the dominant notion of democracy. Today, control, autonomy and distinctiveness escape the (post)modern, postnational state:

If, on the other hand, emphasis is placed on the diminished competence of states, the globalization of national economies, the fragmentation of societies into ethnic, religious, nationality, linguistic and political subgroups, the advent of transnational authorities, and the greater readiness of citizenries to coalesce in public squares, then the end of the Cold War and the emergent arrangements for maintaining social life are likely to 
be viewed as the bases of a wholly new order. States are still active and important, to be sure, but their participation in the processes of world politics is nevertheless of a different, less dominating kind, thereby leading to the interpretation that fundamental systemic change has occurred. (Rosenau 1989: 23)

In this radically altered context, 'Good democratic governance needs both bigger and smaller units' (Bohman 2007: 2).

The literature on governance had come to this conclusion already in the 1960s. Also, domestically, European states had experienced the difficulty of matching effectively services to needs and of devising the appropriate jurisdictional scales to take care of the many tasks they had taken upon themselves. For this reason most European states launched since the 1960s a series of territorial reforms aimed at creating the 'right' territorial partitions that would allow them to deliver public services efficiently while meeting local preferences (Sharpe 1979, 1993). The search for the perfect balance between 'efficiency and community' (Scharpf 2010) has produced a rich literature on federalism and intergovernmental relations. It has also spurred economic theories on the 'optimal size of government' (Oates 1999) that indicate the criteria according to which the territory should be partitioned in such a way that the decisions of the policy-makers and the willingness of policy-takers to accept those decisions will coincide for every given policy issue. Yet it turns out that this is a hopeless quest, which, if consistently applied to all policy issues, leads to fragmentation and having to endorse an extreme notion of multilevel governance (Marks and Hooghe 2000). The same quest for the optimal size of government is now reproduced at global level, with equally elusive results. Bohman's above-cited injunction that the solution lies in finding 'a more complex democratic ideal' can be followed only by engaging in a reformulation of the very principles on which democracy should be based. Among these is the notion of demos, which must be relinquished in favour of a plural notion of demoi.

The 'monism' of a self-legislating people 'cannot provide a theory of democracy consistent with the pluralization of authority and the disaggregation of sovereignty' that we are witnessing (Bohman 2007: 21). Bohman observes an increasing vulnerability of persons to domination - defined as 'arbitrary interference' - and he consequently identifies the new concept of democracy apt for multilevel settings in the republican conception of democracy as non- 
domination (see also Pettit 1997). Individuals are subjected not only to the domination of known political entities like in the past, but also to the domination of 'incompletely defined forms of international political authority that are no longer contained within any political community' (Bohman 2007: 22). The new conception of democracy, therefore, must go beyond the eighteenth-century model of a selflegislating demos that is at once the author and the subject of its laws, and embrace a model in which democracy's subject is potentially the entirety of humanity. Freedom from domination is the basis of what Bohman calls the 'democratic minimum' (Bohman 2007: 5) and the democratic ideal he has in mind is that of 'transnational democracy'.

Bohman also provides us with a working definition of democracy: 'democracy is that set of institutions by which individuals are empowered as free and equal citizens to form and change the terms of their common life together, including democracy itself. In this sense, democracy is reflexive and consists of procedures by which its rules and practices are made subject to the deliberation of citizens themselves. Democracy is thus an ideal of self-determination, in that the terms and boundaries of democracy are made by citizens themselves and not by others' (Bohman 2007: 2). In this new conception of democracy, 'popular control over decision making' takes on a specific meaning: 'it is the interaction between communicative freedom as it is manifested in the public sphere and the normative powers by which people create and control their rights, obligations, and deontic statuses' (Bohman 2007: 5). The most fundamental human right then is the right to initiate deliberation.

This new conception of democracy is highly relevant for our present endeavour, which is to identify the ways in which the CoR contributes to EU democracy. '[T]ransnational democracy - democracy as realized in a variety of institutions and communities - is not only more democratic, but is the only feasible way (for the medium term at least) in which to realize the democratic minimum and rights of the members of the human political community' (Bohman 2007: 5-6). Regardless of whether or not we embrace Bohman's elaboration of transnational democracy in its entirety, on one aspect we definitely agree with him: that 'human rights and non-domination are better realized in a variety of institutions and overlapping political communities' (Bohman 2007: 5-6, emphasis added). This is what makes the CoR not simply a bizarre add-on to the supposedly much more democratic institution of the European Parliament 
(more democratic because it derives its power to legislate from a direct electoral representative mandate) or the Council (more democratic because it is delegated to legislate through an indirect electoral mandate) or even the national parliaments (more democratic because they represent the distinct sovereign demoi), but as one of the institutional settings in which an 'overlapping political community' composed of subnational jurisdictions can contribute to the new conception of democracy.

As we will see, the CoR contributes to democracy as nondomination by constantly reminding delegated national governmental representatives in the Council and directly elected members of the European Parliament of the potential domination inherent in EU legislation or non-legislation (inaction being also a type of action), particularly when only some of the many overlapping demoi are given the possibility of making claims and initiating deliberation. '[D]omination is not simply tyranny nor the ability to interfere arbitrarily. It is . . rule by another, one who is able to prescribe the terms of cooperation. Thus political domination is the arbitrary use of normative powers to impose duties and obligations, and it can operate even against the democratic background of normative expectations. This means that domination is the result of the use of distinctly normative powers' (Bohman 2007: 9, emphasis added). And again, more positively, 'to have robust non-domination is to have a particular kind of normative status, a status allowing one to create and regulate obligations with others. This is the status of non-domination rather than of self-legislation' (Bohman 2007: emphasis added). It is not to be ruled by others, but to rule with others. ${ }^{1}$

As we will see in the empirical chapters, the CoR activity can be certainly construed as contributing both to deliberation (the production of rules and obligations) and to surveillance (the control that these are not simply imposed; see infra for a definition of both). In fact, very often the CoR contributes opinions on EU legislation which defend the right of the subnational demoi of the Union to non-domination, that is, their right not to be 'imposed the terms of cooperation' particularly when such cooperation entails asymmetric costs and limitations on them. In alerting the other EU institutions

1 Hooghe and Marks (1996) made a very similar argument when they elaborated their notion of multilevel governance not as realizing a 'Europe of the regions', but a 'Europe with the regions'. 
of the danger of imposing the terms of cooperation (in an arbitrary, asymmetric way) inherent in some EU legislation, the CoR gives its contribution to EU democracy interpreted as 'the capacity to deliberate and to change the terms of democratic cooperation, and thus have normative power over the distribution of normative powers' (Bohman 2007: 9, emphasis added). In this sense, the contribution of the CoR must not be solely assessed as a contribution to the formation of legislation (will), but as a contribution to deliberation over the terms of democratic governance. ${ }^{2}$

Once more, we can refer to Bohman when he argues that 'this commitment [to democracy as non-domination] demands that rights be realized in a variety of overlapping institutions. Constitutionalism in the European Union ... provides the best example of this sort of a reflexive, democratic and transnational order. In order to be successful it must move beyond the current juridical conception of rights towards a political conception that sees them as rights of membership in the human political community. ${ }^{3}$ It must also become more fully democratic, to the extent that it includes the capacity to reform itself democratically, a capacity it currently lacks sufficient legitimacy to execute' (Bohman 2007: 9, emphasis added).

\section{DEMOCRACY AS JUDGMENT AND WILL}

Let us explore in greater detail the activities through which the CoR contributes to EU democracy. In keeping with a transitional approach to the reformulation of democracy in interdependent settings, we will start from a revised notion of representative democracy (which in itself, according to Bohman, is characteristic of the eighteenth-century notion of democracy as self-legislation) in order to develop an expanded notion of democracy as non-domination. This transitional approach is not uncommon, and was historically used at least once already when political theorists had to theorize

2 For a discussion of the CoR's role in such a new concept of democracy as discussed in the RECON project on 'reconstituting democracy in Europe' (Eriksen and Fossum 2012), see also Schönlau (2010).

3 A first instance in which these debates reached prominence at the political level was the Convention drafting the EU Charter of Fundamental Rights in 1999-2000, where the question of the EU's role in multiple overlapping systems of rights protection figured prominently, see Bellamy and Schönlau (2004), Schönlau (2005). 
the transition from direct democracy to representative democracy - from 'the liberty of the ancients' to 'the liberty of the moderns' (Constant 1819). Because (normative) ideas never quite go out of fashion in political science, representative democracy has been challenged by many quarters also during modern times, and this has prompted Nadia Urbinati to retrieve its genealogy and meaning (Urbinati 2006). In doing this, however, she has provided us with an expanded notion of representative democracy that can serve as a bridge towards the next great transformation to "the liberty of the post-moderns', as it were.

Urbinati distinguishes two principles of political equality: isonomia (the equal right of all to make laws) and isegoria (the equal right of all to speak in the assembly). These identify two fundamental dimensions of both Athenian direct democracy and modern representative democracy: 'the deliberative (as discursive and interpretative, not only decisional) character of democratic politics' (Urbinati 2006: $3)$. Her general argument is that excessive attention to the latter has distracted us from the fundamental importance of the former. This is also the source of the excessive 'juridification' (in Bohman's terms) of contemporary democracy: the identification of the essence of democracy with the right to self-rule, literally as auto-nomy (from the Greek etymology). Urbinati's attempt is to direct our attention to the equal importance of judgment - the articulation of voice, the utterance of discourse, the issuing of interpretations - without which mere selflegislation can give rise to the opposite of democracy: to domination.

The emphasis on judgment is in accord also with Pettit's and Bohman's republican notions of democracy (Athenian democracy is obviously quintessential republican). For Philippe Pettit (1997), who theorizes domination in interpersonal relations, domination as arbitrary interference ensues when 'An act is perpetrated on an arbitrary basis . . . if it is subject just to the arbitrium, the decision or judgment, of the agent; the agent was in a position to choose it or not to choose it, at their pleasure ... when it is chosen or rejected without reference to the interests or opinions of those affected' (Pettit 1997: 55). Consent by the interfered to interference is not sufficient to dispel domination. More precisely, 'what is required for non-arbitrariness in the exercise of a certain power is not actual consent to that sort of power but the permanent possibility of effectively contesting it' (Pettit 1997: 63, emphasis added). The only way to create safeguards against domination is to allow for the permanent possibility to question not 
just the current use of power, but the very institutional structure that allows that power to be exercised. Bohman expresses the same concept in a slightly different way. For Bohman, domination obtains when the public sphere is not activated. In his conception, "popular control over decision making' takes on a specific meaning: 'it is the interaction between communicative freedom as it is manifested in the public sphere and the normative powers by which people create and control their rights, obligations, and deontic statuses' (Bohman 2007: 5). As was recalled above, the most fundamental human right is the right to initiate deliberation. 'This freedom is the basis of what I call the "democratic minimum" (Bohman 2007: 5).

Urbinati develops her attention to the expression of judgment as a fundamental component of democracy as part of her more general agenda to emancipate the notion of representative democracy from that of direct democracy. For many, representative democracy is only a convenient expedient which the moderns use in the objective impossibility of realizing direct democracy in the expanded settings of modern communities. In this sense, modern democracy falls short of Athenian standards. 'Although formally more inclusive than in Athens, popular participation in contemporary democracies is episodic', it is democratic only when 'citizens vote, petition, demonstrate to voice their otherwise ignored or unheard opinions and join social and political movements' (Urbinati 2006: 2). This anomaly is explained by positing contemporary democratic government as a 'mixed constitution', drawing from each pure type (monarchy, oligarchy and democracy).

The legitimacy of representative democracy understood this way is merely procedural as it does not require citizens' participation in legislative deliberation. Yet it is paradoxical to call this type of rule democratic, 'for the only moment the citizens decide directly is when they delegate legislative power. Elections mean that popular sovereignty appears only "at fixed and rare intervals," much like a comet; citizens exercise it "always only to renounce it". A Janusfaced institution, elections give representation a democratic face and democracy an aristocratic twist' (Urbinati 2006: 3). Her goal is to inquire into the conditions under which representation is democratic, that is, a mode of political participation that can activate a variety of forms of citizen control and oversight. She argues that 'representative democracy is an original form of government that is not identifiable with electoral democracy' (Urbinati 2006: 4) 
Like Hanna Pitkin (1967) before her, Urbinati wants to recuperate the full notion of representative democracy by arguing that direct citizen participation in between elections is not only legitimate, but also fully warranted precisely in order to realize 'full and democratic representation'. Also for Urbinati, then, like for Pitkin and Bohman, 'Focus on the presence through ideas and speech reveals participation and representation not as alternative forms of democracy but as related forms constituting a continuum of political judgment and action in modern democracy' (Urbinati 2006: 3, emphasis added). Yet only a minority of theorists considers participation as a support and a complement of representation rather than as an alternative to it. For most 'representative democracy' is an oxymoron because they see representation as an expedient for or a second-best of direct participation. Urbinati wants to rescue the full force of democratic representation and representative democracy and show that 'representation is primed to expand democratic participation and in fact is essential to democracy. ... representative democracy is an original form of government that is not identifiable with electoral democracy' (Urbinati 2006: 4).

The democratic rediscovery of representation is both interesting and compelling. A comprehensive defence of the normative core that makes it democratic is still lacking. 'First, public discourse is one of the main features that characterize and give value to democratic politics, ancient and modern, direct and representative. Voice involves two kinds of active doing: positive (activating and proposing) and negative (receiving and surveiling). ${ }^{4}$ Second, indirectness plays a key role in forging the discursive democratic character of politics, and aids rather than obstructs participation. Third, representation highlights the idealizing and judgmental nature of politics' (Urbinati 2006: 5, emphasis added). In sum 'political representation ... entails a complex political process that activates the "sovereign people" well beyond the formal act of electoral authorization. Representative politics has the power of unifying and connecting the "fluctuating atomic units" of civil society by projecting citizens into a future-oriented perspective' (Urbinati 2006: 5).

In what ways does the CoR contribute to expressing voice, both in its active and in its passive dimensions? Can we identify the ways

4 The verb 'to surveil' does not exist, only the noun 'surveillance'. However, in the remainder of this book, we will use it and conjugate it as if it did exist. 
in which the CoR activates, proposes, receives and surveils the other EU institutions? Does the CoR initiate deliberation over the terms of EU cooperation? We argue that the CoR does precisely all of this: even if it does not directly contribute to the expression of will, understood as the direct power to legislate and/or veto legislation, its activity is nonetheless crucial for EU democracy.

It is clear that, while CoR members actively participate in the discussion of many EU policy and political issues - that is, they are fully involved in the activation, proposal, reception and surveillance associated with voice (which gives substance to the democratic principle of isegoria, the equal right of all to speak) - they are not directly involved in the activities that express will (which brings about isonomia, the equal right of all to participate in legislation). Moreover, while they are involved in control - particularly through their role as guardians, together with national parliaments, and via the European Court of Justice, of the principle of subsidiarity - they are not, contrary to members of the EP, directly involved in the application of sanctions. Is it reasonable to argue that the CoR might nevertheless deliver democratic representation? What kind of concrete actions can CoR members take on behalf of their constituents? In answering these questions we will particularly concentrate on Urbinati's treatment of democracy as isegoria. While subnational constituencies (of various sizes, wealth and powers) may appear to be disempowered when it comes to directly influencing decisions (will), we will argue that they are surprisingly powerful when it comes to expressing their constituents' interests and wishes (judgment) by performing all four actions identified by Urbinati: activating, proposing, receiving and surveiling. In fact, we will argue that the CoR's relative legislative powerlessness amplifies its deliberative powers.

\section{JUDGMENT: VOICE AND SURVEILLANCE}

Most contemporary political theorists conceive of representation as an ongoing dialogue between citizens and representatives that does not simply occur every so often, at election times, but that continues also in between elections. This 'dialogical notion of representation' (Piattoni 2013) is already present in Pitkin's elaboration of 'full political representation' (Pitkin 1967). For her: 
representing here means acting in the interest of the represented in a manner responsive to them. The representative must act independently; his actions must involve discretion and judgment; he must be the one who acts. The represented must also be (conceived as) capable of independent action and judgment, not merely being taken care of. And, despite the resulting potential for conflict between representative and represented about what is to be done, that conflict must not normally take place. The representative must act in such a way that there is no conflict, or if it occurs an explanation is called for. He must not be found persistently at odds with the wishes of the represented without good reason in terms of their interests, without a good explanation of why their wishes are not in accord with their interests. (Pitkin 1967: 209-10)

The two extremes of this relationship - the trustee, who never consults with the represented and relies uniquely on his judgment in pursuing their interests, and the delegate, who consults with the represented whenever he has to act and has no opinion of his own - lie outside the concept of representation altogether. Pitkin squarely rejects a notion of democracy as 'democracy of the experts' or 'technocratic democracy'. 'The more a political theorist sees political issues as questions of knowledge, to which it is possible to find correct, objectively valid answers, the more inclined he will be to regard the representative as an expert and to find the opinion of the constituency irrelevant.... On the other hand, the more a political theorist takes political issues to be arbitrary and irrational choices, matters of whim or taste, the less it makes sense for a representative to barge ahead on his own ignoring the tastes of those for whom he is supposed to be acting' (Pitkin 1967: 211). However, 'Political issues, by and large are found in the intermediate range, where the idea of representing as a substantive acting for others apply. Political questions ... are questions about actions, about what should be done; consequently they involve both facts and value commitments, both ends and means. And, characteristically, the factual judgments, the value commitments, the ends and the means are inextricably intertwined in political life' (Pitkin 1967: 212). For this reason, no political issue can be prevented from becoming the object of citizens' deliberation.

Pitkin concludes that 'the representative must pursue his constituents' interests in a manner at least potentially responsive to their wishes, and that conflict between them must be justifiable in terms of that interest' (Pitkin 1967: 213, emphasis added). In other words, the represented can always make known to their representatives whether or not they think that their interests are being pursued according to 
their own understanding. Pitkin further clarifies that 'common deliberation' between represented and representative is aimed precisely at resolving such conflicts, and to the extent that it fails, 'the possibility for substantive acting for others breaks down' (Pitkin 1967: 213). Lastly, in addressing the tension between representing the general interest and representing the interest of the narrower constituencies, Pitkin avoids naively assuming that they should naturally coincide but rather appeals again to the interactive construction of such a unity. 'The national unity that gives localities an interest in the welfare of the whole is not merely presupposed in representation; it is also continually recreated by the representative' (Pitkin 1967: 218, emphasis added).

Obviously, this applies a fortiori to a diverse polity like the European Union. As if to dispel any doubts that representation could be a static and simple relationship, Pitkin concludes that:

Political representation is primarily a public, institutionalized arrangement involving many people and groups, and operating in the complex ways of large-scale social arrangements. What makes it representation is not any single action by any one participant, but the overall structure and functioning of the system, the patterns emerging from the multiple activities of many people. It is representation if the people (or a constituency) are present in governmental action, even though they do not literally act for themselves. Insofar as this is a matter of substantive acting for others, it requires independent action in the interest of the governed, in a manner at least potentially responsive to them, yet not normally in conflict with their wishes. (Pitkin 1967: 221-2)

In line with Hanna Pitkin and Philippe Pettit, Nadia Urbinati and James Bohman use very similar words to indicate the dialogical and deliberative nature of representative democracy. In his theorization of liberty as non-domination, Pettit (1997) insists on the necessity for the rulers to decide only after having accurately tracked the ideas and interests of the ruled, according to how they themselves end up conceiving them after collective deliberation. The public sphere is the locus in which such deliberation must take place. As we saw, Bohman conceives democracy and non-domination and identifies non-domination primarily with the right of participation in deliberation. ${ }^{5}$

5 Richard Bellamy and Dario Castiglione make a similar argument and call it 'the right to have rights' (Bellamy and Castiglione 2003). 
Democracy is that set of institutions by which individuals are empowered as free and equal citizens to form and change the terms of their common life together, including democracy itself. In this sense, democracy is reflexive and consists of procedures by which its rules and practices are made subject to the deliberation of citizens themselves. Democracy is thus an ideal of self-determination, in that the terms and boundaries of democracy are made by citizens themselves and not by others. (Bohman 2007: 2, emphasis added)

We have already recalled above how, for Bohman, the central feature of this new conception is that 'it is a reflexive order, an order in which people deliberate together concerning both their common life and the normative and institutional framework of democracy itself' (Bohman 2007: 5, emphasis added). Voice in both its active proposing and activating and in its passive receiving and surveiling implies communicative freedom in the public sphere.

\section{THE ROLE OF SUBNATIONAL AUTHORITIES IN EU DEMOCRACY}

In the process of reconstructing the genealogy of representative democracy, Urbinati reports the eighteenth-century French philosopher Condorcet's ideas on democracy and constitutionalism, which combined both a juridical and a political conception of sovereignty. Moreover, for Condorcet all laws should be open to revision and revocation and all political functions should be elective. Politics for him was 'a reflective movement of judgment that each citizen could activate over any public issue, law and institution through the formal channels devised in the constitution as well as the informal channels guaranteed by civil rights. Society and the government, public opinion and deliberative institutions were in a permanent and dynamic dialogue' (Urbinati 2006: 181, emphasis added).

Condorcet's sovereign citizens were given the right and opportunity to be active whenever they deemed it useful or necessary and could influence the legislative process directly, not simply by electing representatives. Condorcet is an interesting example of a third-way solution that defies the two mirror-like radical approaches that have monopolised the debate over modern democracy since the eighteenth century: the mystique of sovereignty as immediate and existential presence (direct democracy as ultimate ideal) and the idea 
of electoral democracy as the denial of sovereignty as autonomy (representative democracy as a necessary, but unsatisfactory expedient given the objective impossibility of having direct democracy). Condorcet redirected participation from a passionate-emotional kind of virtue to a discursive-judgmental type and prefigured the transition of classical republicanism to a deliberative kind of democracy. 'So although he retained Rousseau's usage and described sovereignty in terms of will, he actually focused on the processes that preceded and followed the moment of decision and therefore transformed the issue of sovereignty into an issue of opinion formation, reflection, revision, and amendment' (Urbinati 2006: 184).

In a way, Condorcet anticipated the 'systemic' view of politics (Easton 1953, 1965), which begins outside of government, reaches political institutions and returns to society where it starts its path all over again, since the citizens have the right to propose abrogative referenda or new laws. Strangely, this vision is similar to the European Commission's view of the role of subnational authorities and civil society organizations produced in the White Paper on European Governance (COM 2001), which was perhaps all too quickly lambasted for doggedly defending the Community method, for promoting a technocratic view of policy-making in the EU and for privileging large business interests over subnational and civil society concerns (Joerges, Mény and Weiler 2001). Condorcet includes both formal and informal types of discussions within the category of deliberation. 'Deliberation starts with many I's to gradually produce some $W e$ 's and finally concludes with one approving $W e$. The "general will" is thoroughly a process of filtering "personal" and "partial" views' (Urbinati 2006: 204, emphasis in the original). In referring to Condorcet's specific contribution to the theorization of representative democracy as a democratic type in its own right, and not just a second best to direct democracy, Urbinati calls attention to his idea of using what he termed 'primary representative assemblies' in order to articulate the people's voice and exert surveillance. What Condorcet had to say about 'primary assemblies' is very interesting, particularly from the point of view of our analysis of the CoR's contribution to EU democracy.

Condorcet's purpose was to make 'local knowledge a resource in the creation of the political agenda and an element of the "true interest of the nation" (principle of circularity and participation) and preventing corporate interests from taking over the national politics 
(principle of equality)' (Urbinati 2006: 209-10). Particularly relevant for the refutation of the argument according to which the CoR is supposedly a minor institution because it has no direct input over the expression of will is Urbinati's emphasis on the articulation of voice and the exertion of surveillance. Urbinati remarks, referring again to Condorcet, that 'No act of the will was absolute and unique because sovereignty did not reside exclusively in the will but in the judgment over the pronouncement of the will' (Urbinati 2006: 210, emphasis added). In giving the citizens the negative power to surveil governmental action and repeal unjust laws, Condorcet signalled the limits of elections in making representatives accountable, hence exposing the inherent limits of representation as delegation (Piattoni 2013).

He did not endorse delegation à la Rousseau or à la Marx. . . . The dissolution of the representative assembly as an effect of the negative right of the citizens was the product of the principle of circularity between extraparliamentary and parliamentary spheres. It prefigured a conception of the political mandate that allowed for some form of control over the representatives but did not fall to the principal/client form of contractual delegation. Although representatives could not be subjected to any legal mandate, they could and should be subjected to a political mandate. (Urbinati 2006: 218)

Most remarkable in view of our theorization of the CoR's unique contribution to EU democracy are Condorcet's ideas on the contribution of primary assemblies to democracy.

Primary assemblies were Condorcet's most important attempt to revise this view and implement indirect democracy. They were meant to transform the abstract space of the legal nation into a network of physical sites within which citizens could set up a deliberative dialogue with the broader nation. Primary assemblies were physical sites (neighborhood headquarters open seven days a week and particularly on Sundays to accommodate working citizens' needs) where any citizen could go to consult the official bulletins on the legislative activity of the national assembly; to present her proposal to amend an existing law and submit it to discussion and vote; to vote on proposals coming from other assemblies; or simply to select candidates and vote for representatives. (Urbinati 2006: 208)

Even more forcefully, Condorcet conceived the constitution as guaranteeing the citizens the right to resist a law that is evidently unjust although promulgated by a legitimate power. 'His plan was 
set out to prove that what gives the sovereign an active political presence and security against the decision of the majority is not so much electoral authorization of law-makers or direct ratification of laws as réclamation, a right that operates over representatives' work and follows a rigorous and regulated course of judgment. ... Condorcet's constitution gave the citizens the power to stop a law before it was promulgated or to repeal it afterwards' (Urbinati 2006: 213 , emphasis added). This is where the CoR could make its distinctive contribution. However, Condorcet went further and proposed that primary assemblies should have the power to call into question the representativeness of national assemblies. The right to repeal applied directly to 'all the laws, and generally to any acts of the legislature that were against the constitution and has two effects: that of dissolving the National Assembly and that of imposing a pause (a term limit) on the right of the representatives to be reelected. Any citizen could start a motion of appeal' (Urbinati 2006: 215). 'Elections, when they are associated with the right to call on new elections, are not simply meant to designate new representatives but to check over their representativity. Their real goal is to construct and reconstruct or "re-establish an accord between the citizens and the national representation that was broken"' (Urbinati 2006: 216). This 'reconstructive' role could indeed be taken up by the CoR even without the corresponding right to dissolve national assemblies or to impose a pause on the right of representatives to be reelected.

Starting from a particular understanding of contemporary democracy as counter-democracy, Pierre Rosanvallon (2008) also puts emphasis on surveillance and judgment as fundamental democratic components. Rosanvallon's conception of democracy encompasses not only the formal, legal and constitutional practices of democratic regimes, but also those limiting and correcting mechanisms, whether constitutional or extra-constitutional, by which the people attempt to impose control over the political processes carried out in their name. This is 'counter-democracy'. Among the various ways in which the people are able to check and hold to account their representatives or their governments irrespective of the electoral process are: (1) powers of oversight or surveillance; (2) forms of prevention; and (3) the testing of judgment. Rosanvallon's premise is that democracy is as much about securing legitimacy (through procedural and institutional provisions) as it is about checking representatives and governments (through institutional and non-institutional mechanisms 
of distrust). He therefore examines the "manifold manifestations of distrust in a comprehensive framework'. In short, he wishes to understand 'the manifestations of distrust as elements of a political system' (Rosanvallon 2008: 5).

The expression of distrust can take two main forms: liberal and democratic. Montesquieu gave the canonical expression to the liberal notion of distrust and the founding fathers of the American state gave it constitutional form, that is, respectively the principles of division of powers and of checks-and-balances. The purpose of the democratic form of distrust is not to limit the potential encroachment of elected powers onto individual citizens, but to 'make sure that elected officials keep their promises and find ways of maintaining pressure on the government to serve the common good' (Rosanvallon 2008: 8), an effort that was central to Pitkin's definition of 'full political representation' and which has triggered a reconceptualization of representation in an effort to build within the representative relation responsiveness safeguards (Mansbridge 2003, Rehfeld 2009).

According to Rosanvallon, the democracy of distrust has emerged in recent decades, particularly as a consequence of the emergence of what Ulrich Beck calls the 'risk society' (Beck 1992). Among the heightened risks that today's societies face are those stemming from growing interdependence and globalization, and also those deriving from deepening European integration, even though the latter is sometimes presented as a safeguard against the negative effects of globalization. A sort of resentment is therefore mounting against those decision-makers and scientists who present globalization as a sort of inevitable and ideal end-station which, supposedly, favours the full unleashing of the human potential. Given that globalization carries with it asymmetric risks and potential for domination, distrust has become a prominent feature of current democracies. 'While in the past technological progress was seen as a positive development, it is now seen as carrying new and more complex risks: scientists are at the same time the makers of progress and the only ones who can help us assess the risks involved. Economists are also the targets of citizens' distrust. They had preached the marvels of macroeconomic management, and now they can only register impotence'. Both developments have bred a 'heightened suspicion of authority' in 'a society of estrangement'.

Rosanvallon recalls that popular sovereignty historically found 
expression in two forms: the right to vote and to right to surveillance. As we have seen, the right to vote is exercised periodically: the legitimacy that it bestows upon elected government is always accompanied by a wish to exercise a more permanent form of control over the government thus elected. A complementary form of sovereignty, oversight or surveillance, embodied the desire of the people to oversee the work of government, to watch over 'representative entropy' (that is, the degradation of the relationship between voters and their representatives). There are three primary modes of oversight - vigilance, denunciation and evaluation - largely coinciding with the sort of activities that Urbinati calls receiving and surveilling.

Sanction and prevention constitute a second fundamental form of distrust. Success in blocking the passage of an undesired piece of legislation is evident to everyone, while the passage of a law is a longer and more complex activity that may also fail. 'Increasingly, therefore, popular sovereignty manifests itself as a power to refuse, both in periodic elections and in repeated reactions to government decisions. A new "democracy of rejection" has thus superimposed itself onto the original "democracy of proposition". Democratic government is no longer defined solely as a procedure of authorization and legitimation. Its structure is essentially defined by permanent confrontation of various types of veto from different social groups' (Rosanvallon 2008: 16). A third type of counter-democracy is the advent of the people as judge. The 'judicialization of politics' - not to be confused with Bohman's purported juridification of politics, as discussed above - 'is the most obvious manifestation of this. It is as though citizens hope to receive from a judicial process of some sort what they despair of obtaining from the ballot box. Judicialization should be seen against the backdrop of declining government responsiveness to citizens' demands. As responsiveness declines, the desire for accountability increases. Democracy of confrontation gives way to democracy of accusation' (Rosanvallon 208: 16, emphasis in the original).

It is clear that Rosanvallon describes a situation which probably neither Bohman nor Urbinati would find satisfactory, but his objective is different. He does not want to track the genealogy of representative democracy or to theorize democracy in interdependent settings, he merely wants to account for those manifestations of counter-democracy that, far from being democratic pathologies, are typical manifestations of the current notion of democracy both 
as proposition and activation, but also and much more as reception (or rejection) and surveillance. While the $\mathrm{EU}$ is nowhere close to a conventional democracy, it elicits some of the same distrustful reactions vis-à-vis scientists, experts and economists as national democracies (and some specific to itself). The CoR can thus contribute specifically to the first two types of 'counter-democratic' practices described by Rosanvallon - oversight and surveillance, in turn divided into vigilance, denunciation and evaluation - leaving the other activities - sanction, prevention and judgment - to other actors like civil society organizations, the media and the judiciary as well as spontaneously mobilized citizens. All of these activities are in tune with the more recent theorizations of accountability as involving a multiplicity of actors, addressing a multiplicity of forums and following a multiplicity of criteria (Bovens 2007).

\section{THE CONTRIBUTION OF THE COR TO EU DEMOCRACY}

To conclude, it would appear that the CoR can contribute to EU democracy in several fundamental, and not marginal, ways. First, it can help articulate voice by mobilizing the local knowledge that is dispersed in the many places of Europe. It can do so by 'upgrading' territorial interests into more categorical interests (Piattoni 2012), so that they escape the particularities of places, by transforming 'the many separate We's into a deliberating We' (rephrasing Urbinati's quote). It can furthermore exert surveillance, that is, oversee the democratic implications of EU legislation - whether it treats all with equal respect and whether it accords to everyone the right of voice and deliberation - and watch over their differentiated impact on different European locations and different sets of European citizens, and thus avoid asymmetric domination of the few over the many. It can moreover stand guard over the constitutional right of all people to contribute to deliberation, and thus avoid that decisions are made without the necessary input of the various communities that make up the Union. In a word, the CoR can contribute to democracy as non-domination as well as to representative democracy in Urbinati's rich sense.

Far from being a minor and somewhat redundant institution, the CoR is uniquely positioned to exert judgment, in both its active 
and passive dimensions, precisely because it is not directly involved in the expression of will. If it were, the temptation for CoR members to represent the interests of their own particular territory and community, and to veto decisions that run counter to them, rather than the common interests of all territories and communities, would be very strong. Particularly given the fact that CoR members are either local chief-executives or elected members of local representative assemblies, the temptation to use the blackmailing potential to withhold consent in exchange for particular benefits for this or that territory or community deriving from EU legislation would trigger rather insurmountable 'joint-decision traps' (Scharpf 2010). The fact that the CoR has only a consultative mandate ensures that it will use its voice to the benefit of the entire European community. A possible direct involvement of the CoR in EU law-making, on the other hand, would make sense only in the context of a more fundamental re-balancing of the EU's institutional/representative system involving further institutional innovations such as trans-European lists for the European Parliament elections, the development of the European Commission into a transnational executive, and clearer definition of the constituent elements of EU democracy. We will come back to these questions in the concluding chapter. 